\title{
Rancang Bangun Mesin Penjual Beras Berbasis Mikrokontroler Atmega16
}

\author{
Diana Rahmawati ${ }^{1}$, Khoirul Anam ${ }^{2}$, Achmad Ubaidillah $\mathrm{Ms}^{3}$, dan Kunto Aji W \\ 1,2,3,4 Jurusan Teknik Elektro, Program Studi Teknik Elektro, Universitas Trunojoyo \\ J1. Raya Teklang PO. BOX 2, kecamatan kamal bangkalan, madura 69162 \\ e-mail: diana.rahmawati@trunojoyo.ac.id
}

\begin{abstract}
Abstrak-Rancang bangun mesin penjual beras merupakan suatu inovasi baru yang dirancang agar bermanfaat bagi masyarakat. Cara kerja alat ini adalah menginputkan nilai rupiah dengan keypad. Setelah memilih jenis beras dan memasukkan jumlah yang ingin dibeli, servo akan membuka dan proses timbang. Servo menutup ketika proses timbang selesai. Informasi transaksi penjualan diprint dalam bentuk nota dengan printer nota. Pada alat ini juga terdapat pengaturan untuk mengganti harga beras. Untuk sekali proses pembelian beras 1.000 gram membutuhkan waktu 30 detik dari awal beras keluar sampai set point. Dari 150 percobaan yang telah dilakukan sebanyak 129 percobaan berhasil menimbang dengan selisih < 15 gram dan 21 percobaan selisih > 15 gram. Selisih $<15$ gram sudah termasuk bagus untuk alat ini. Rata-rata keberhasilan menimbang beras sebesar 86\% yang memiliki selisih < 15 gram.
\end{abstract}

Kata kunci: Sensor loadcell, Servo, Mikrokontroler Atmega16.

\begin{abstract}
The design of the rice vending machine is a new innovation designed to benefit the community. The way this tool works is to input the rupiah value with the keypad. After selecting the type of rice and entering the amount you want to buy, the servo will open and process the weigh. The servo closes when the weighing process is complete. Sales transaction information is printed in the form of notes. In this tool there are also settings to change the price of rice. For one thousand grams of rice, the purchase process takes 30 seconds from the beginning of the rice to the set point. Of the 150 experiments that have been carried out, 129 trials were successful in weighing a difference of $<15$ grams and 21 experiments with a difference of $>15$ grams. A difference of $<15$ grams is good for this tool. The average success rate weighing rice is $86 \%$ which has a difference of $<15$ grams.
\end{abstract}

Keywords: Loadcell sensor, Servo, Mikrokontroler Atmega16.

\section{PENDAHULUAN}

Timbangan adalah alat yang dipakai melakukan pengukuran massa suatu benda. Timbangan dikategorikan kedalam sistem mekanik dan juga elektronik. Timbangan kebanyakan digunakan dalam proses jual beli suatu benda, dahulu timbangan yang digunakan masih dalam bentuk analog sehingga keakuratan hasil masih di pertanyakan.

Sebagian orang menggunakan timbangan meja untuk menimbang beras. Penjual melayani pembeli dengan cara mengambil beras dalam karung kemudian ditimbang. Setelah itu beras diwadahi kresek. Jika pembeli ingin membeli beras dengan uang seadanya atau dengan satuan rupiah, pedagang harus melakukan perhitungan dahulu dengan kalkulator berapa gram beras yang didapat dengan uang yang pembeli tersebut miliki.

Tujuan yang ingin dicapai dalam penelitian ini adalah membuat rancang bangun mesin penjual beras. Dengan adannya alat ini diharapkan dapat membantu masyarakat dalam proses jual beli beras. Keunggulan dari alat ini yaitu konsumen dapat membeli beras dengan satuan rupiah dengan cara menginputkan nilai rupiah dengan keypad. Tersedia 3 macam jenis beras dengan harga dan kualitas yang berbeda. Penjual juaga dapat mengganti harga tanpa membuka program.

\section{STUDI PUSTAKA}

\section{A. Mikrokontroler}

Mikrokontroller merupakan suatu sistem komputer yang seluruh atau sebagian besar elemennya dikemas dalam satu chip IC, sehingga sering juga disebut dengan single chip mikrokomputer. Mikrokontroller biasa dikelompokkan dalam satu keluarga, masing-masing mikrokontroller mempunyai spesifikasi tersendiri namun masih kompatibel dalam pemrogramannya.[1]

Pada rancang bangun mesin penjual beras ini saya menggunakan mikrokontroler atmega16.

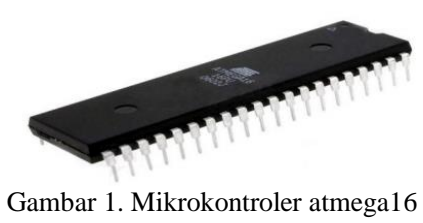

\section{B. Sensor Loadcell}

Sensor loadcell adalah suatu alat transducer yang menghasilkan output yang proporsional dengan beban atau gaya yang diberikan. Sensor loadcell digunakan untuk 
mengkonversikan regangan pada logam ke tahanan variabel [2]

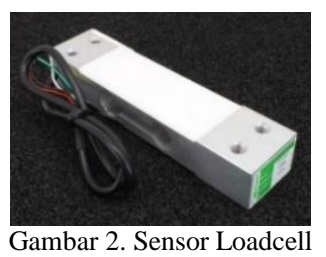

Untuk terhubung ke mikrokontroler sensor loadcell membutuhkan modul hx711. Prinsip kerjanya adalah mengkonversi perubahan.yang terukur dalam perubahan resistansi dan mengkonversinya ke dalam besaran tegangan melalui rangkaian yang ada. [2]

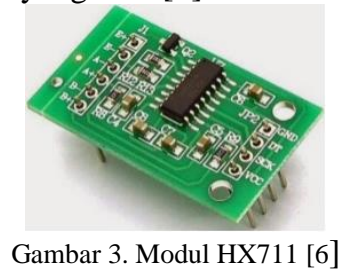

\section{Servo}

Motor servo adalah sebuah motor dengan sistem closed feedback di mana posisi dari motor akan diinforrnasikan kembali ke rangkaian kontroI yang ada di dalam motor. Motor servo biasanya hanya bergerak mencapai sudut tertentu saja. [3]

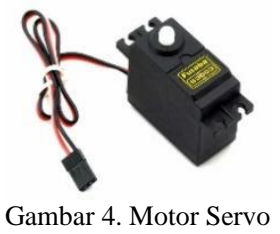

\section{LCD (Liquid Cristal Display)}

LCD berfungsi untuk menampilkan karakter angka, huruf ataupun simbol dengan lebih baik dan dengan konsumsi arus yang rendah. Jenis dan ukuran LCD bermacam-macam, antara lain $1 \times 16,2 \times 16,2 \times 20,2 \times 40$, dan lain-lain.[4]. LCD menampilkan data baik dalam bentuk karakter, huruf, angka ataupun grafik [9]. Pada pembuatan alat ini saya menggunkana lcd 20x4.

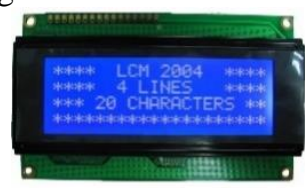

Gambar 5. LCD 20x4

\section{E. Keypad}

Keypad adalah bagian penting dari suatu perangkat elektronika yang membutuhkan interaksi manusia. Keypad berfungsi sebagai interface antara perangkat elektronik dengan..manusia atau dikenal dengan HMI (Human Machine Interface). [10]

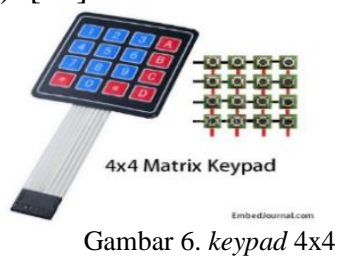

III. METODE

\section{A. Perancangan Perangkat Keras}

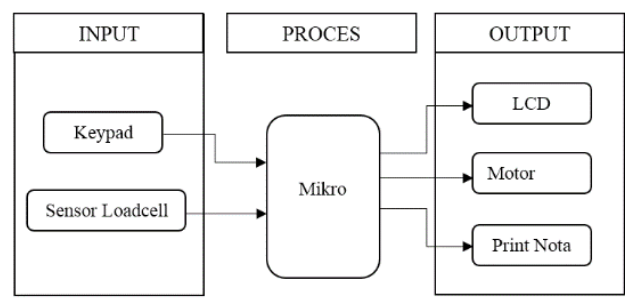

Gambar 7. Blog Diagram

Perangakat keras yang digunakan pada rancang bangun mesin penjual beras ini adalah mikrokontroler atmega16 sebagai pengolah data, sensor loadcell atau sensor beban sebagai pendeteksi berat beras dan motor servo untuk membuka dan menutup saluran beras. Selain itu terdapat juga perangkat lainnya seperti keypad, LCD 4x20 dan printer nota.

\section{B. Desain Perangkat Keras}

Berikut merupakan desain dari rancang bangun mesin penjual beras yang akan dibuat:
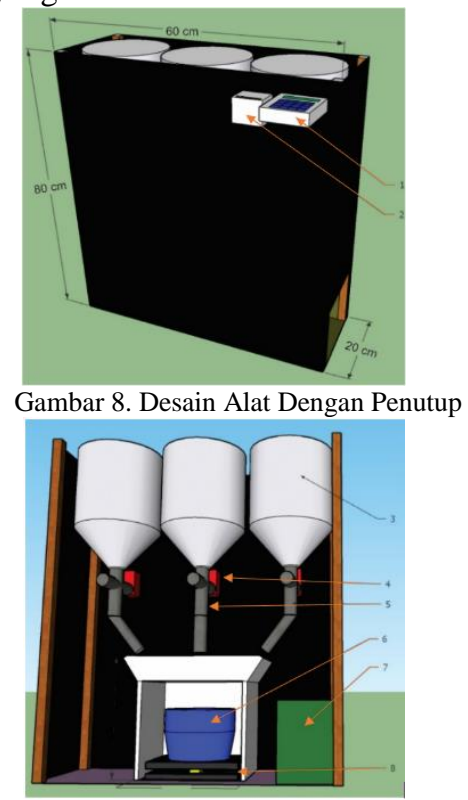

Gambar 9. Desain Alat Tanpa Penutup

\begin{tabular}{|l|l|l|}
\hline No & Nama Bagian & \multicolumn{1}{|c|}{ Penjelasan Bagian } \\
\hline 1 & $\begin{array}{l}\text { Tempat LCD } \\
\text { dan keypad }\end{array}$ & $\begin{array}{l}\text { Sebagai tempat LCD dan keypad. } \\
\text { LCD berfungsi untuk menampilkan } \\
\text { input dari keypad dan menampilkan } \\
\text { berat dari loadcell ketika proses } \\
\text { menimbang. }\end{array}$ \\
\hline 2 & $\begin{array}{l}\text { Tempat cetak } \\
\text { nota }\end{array}$ & $\begin{array}{l}\text { Tempat cetak nota setelah proses } \\
\text { menimbang selesai. }\end{array}$ \\
\hline 3 & Tandon beras & $\begin{array}{l}\text { Sebagai tempat menyimpan beras } \\
\text { yang akan dibeli. Terdapat 3 tandon } \\
\text { beras, masing-masing memiliki } \\
\text { kapasitas 5.000 gram. }\end{array}$ \\
\hline
\end{tabular}




\begin{tabular}{|l|l|l|}
\hline \hline 4 & Servo & $\begin{array}{l}\text { Servo untuk membuka dan menutup } \\
\text { saluran beras. Terdapat 3 buah servo } \\
\text { yang berada pada setiap pipa. }\end{array}$ \\
\hline 5 & Paralon/Pipa & $\begin{array}{l}\text { Sebagai saluran beras. Beras dari } \\
\text { tandon beras ke wadah beras } \\
\text { disalurkan melalui pipa. }\end{array}$ \\
\hline 6 & Wadah Beras & $\begin{array}{l}\text { Sebagai tempat beras yang akan } \\
\text { timbang. Beras yang akan dibeli } \\
\text { dimasukkan didalam wadah beras } \\
\text { untuk ditimbang. Memiliki } \\
\text { kapasitas 3.000 gram. }\end{array}$ \\
\hline 7 & $\begin{array}{l}\text { Tempat } \\
\text { elektronika }\end{array}$ & $\begin{array}{l}\text { Tempat dimana akan digunakan } \\
\text { untuk menaruh mikrokontroler } \\
\text { atmega16 dan komponen } \\
\text { pendukung lainnya }\end{array}$ \\
\hline 8 & $\begin{array}{l}\text { Timbangan } \\
\text { alat }\end{array}$ & $\begin{array}{l}\text { Pada timbangan alat terdapat sensor } \\
\text { loadcell sebagai deteksi berat beras. } \\
\text { Beras yang ada dalam wadah beras } \\
\text { ditimbang oleh loadcell dan } \\
\text { beratnya akan ditampilkan pada } \\
\text { LCD. }\end{array}$ \\
\hline
\end{tabular}

C. Rangkaian Alat

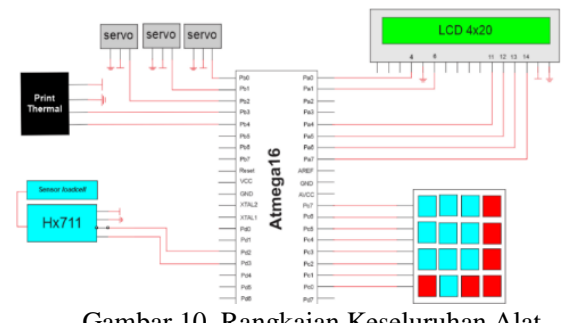

Rangkaian keseluruhan rancang bangun mesin penjual beras terdiri dari beberapa input dan output. Pengolah data yang digunakan adalah mikrokontroler Atmega16. Input yang diolah atmega16 adalah data dari keypad, kemudian output nya berupa LCD, sensor loadcell, servo dan printer nota. Interface keypad dengan Atmega16 berapa pada pin C. Sedangkan interface sensor loadcell berada pada pin B, LCD berada pada pin A, servo dan printer nota pada pin $\mathrm{D}$.

\section{Cara Kerja Alat}
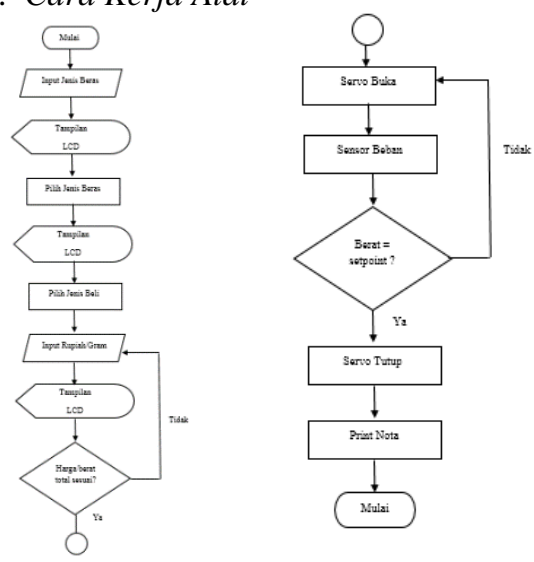

Gambar 11. Flowchart
Cara kerja alat dimulai dari input pilih beras dan mode beli dengan keypad. Kemudian data diolah mikrokontroler dan dieksekusi oleh servo dan sensor loadcell. Jika nilai loadcell tidak sama dengan setpoint maka servo masih terbuka, proses penimbangan masih berlanjut. Ketika loadcell sudah sama dengan setpoint maka servo memberikan respon berupa penutupan lubang. Setelah proses penimbangan selesai maka print akan mencetak nota transaksi

\section{E. Perncangan Perangkat Keras}

Pada alat ini membutuhkan sofware berupa code vision AVR untuk memprogram mikrokontroler atmega16. Dan dibutuhkan sofware exteme burner untuk penguploadan program ke mikrokontroler atmega16 yang berformat .hex

\section{HASIL DAN PEMBAHASAN}

\section{A. Hasil Perancangan}

Setelah dilakukan perancangan jadilah mesin penjual beras menggunakan mikrokontroler atmega16 sebagai berikut :

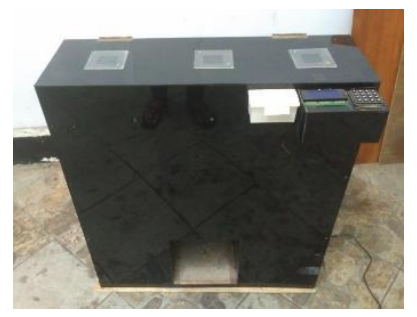

Gambar 12. Rancang Bangun Mesin Penjual Beras

Spesifikasi Alat

\begin{tabular}{|l|l|l|}
\hline No & Nama & Keterangan \\
\hline 1 & Dimensi alat & $60 \times 20 \times 80$ \\
\hline 2 & Kapasitas per wadah & $\pm 5 \mathrm{Kg}$ \\
\hline 3 & Kapasitas wadah timbang & $3 \mathrm{Kg}$ \\
\hline 4 & Jenis prosesor & Atmega16 \\
\hline 5 & Voltage & $5 \mathrm{~V}$ \\
\hline 6 & Ampere & $2 \mathrm{~A}$ \\
\hline
\end{tabular}

\section{B. Kalibrasi Sensor Loadcell}

Pengujian ini bertujuan untuk mengkalibrasi timbangan alat dan timbangan digital.
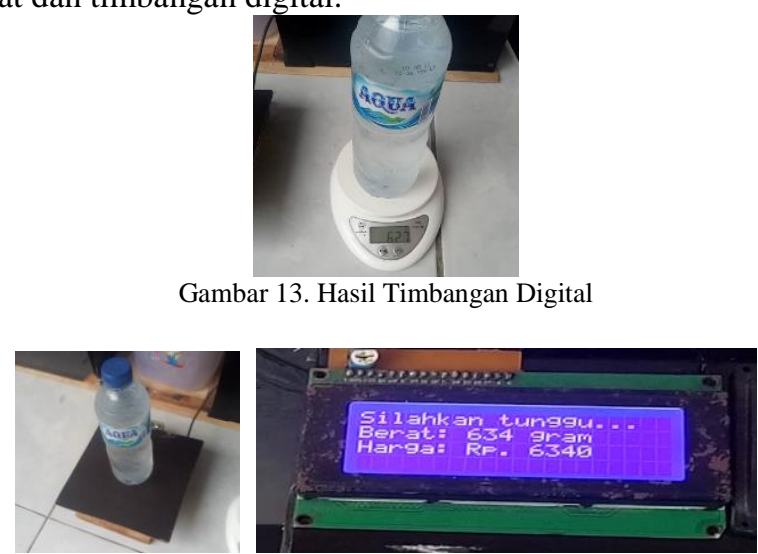

Gambar 14. Hasil Timbagan Alat 
Dari hasil percobaan yang telah dilakukan sensor loadcell berjalan dengan baik terbukti dengan keberhasilan mendeteksi berat dan hasil di tampilkan pada LCD 20x4. Untuk kalibrasi timbangan alat menggunakan aqua botol $600 \mathrm{ml}$. Dengan cara, meletakkan aqua botol di timbangan digital dan melihat hasilnya. Kemudian memindahkan botol aqua tesebut pada timbangan alat dan melihat hasilnya. Terakhir mengkalibrasi timbangan alat sesuai timbangan digital.

\section{Pengujian Sensor Loadcell}

Pengujian sensor loadcell juga dilakukan dengan cara melakukan percobaan sebanyak 5 kali dengan inputan sama, untuk mengetahui apakah pemasangan sensor loadcell sudah benar atau .masih perlu diperbaiki

Tabel Percobaan

\begin{tabular}{|c|c|c|}
\hline Percobaan & Input & Hasil \\
\hline 1 & Rp 5.000 & 507 gram \\
\hline 2 & Rp 5.000 & 507 gram \\
\hline 3 & Rp 5.000 & 507 gram \\
\hline 4 & Rp 5.000 & 507 gram \\
\hline 5 & Rp 5.000 & 507 gram \\
\hline
\end{tabular}

Dari hasil percobaan yang telah dilakukan sensor loadcell berjalan dengan normal terbukti percobaan 5 kali dengan inputan sama hasilnya juga sama

\section{Pengujian Pembelian Beras}

Percobaan pembelian beras dilakukan deengan cara melakukan pembelian sebanyak 50 kali pada setiap jenis beras. Hasil timbang alat akan dibandingkan menggunakan timbangan digital agar diketahui berapa gram selisih antara keduanya.

\section{Beras A (harga Rp 10.000/kg)}

\begin{tabular}{|c|c|c|c|c|}
\hline \multirow[b]{2}{*}{ No } & \multirow[b]{2}{*}{ Pembelian } & \multicolumn{2}{|c|}{ Hasil } & \multirow[b]{2}{*}{ Sesilih } \\
\hline & & $\begin{array}{c}\text { Timbangan } \\
\text { Alat }\end{array}$ & $\begin{array}{c}\text { Timbangan } \\
\text { Digital }\end{array}$ & \\
\hline 1 & Rp. 1.000 & 100 gram & 112 gram & 16 gram \\
\hline 2 & Rp. 2.000 & 200 gram & 210 gram & 16 gram \\
\hline 3 & Rp. 3.000 & 300 gram & 308 gram & 16 gram \\
\hline 4 & Rp. 4.000 & 400 gram & 409 gram & 9 gram \\
\hline 5 & Rp. 5.000 & 500 gram & 507 gram & 7 gram \\
\hline 6 & Rp. 6.000 & 600 gram & 607 gram & 7 gram \\
\hline 7 & Rp. 7.000 & 700 gram & 704 gram & 4 gram \\
\hline 8 & Rp. 8.000 & 800 gram & 807 gram & 7 gram \\
\hline 9 & Rp. 9.000 & 900 gram & 905 gram & 5 gram \\
\hline 10 & Rp. 10.000 & 1.000 gram & 1.003 gram & 3 gram \\
\hline 11 & Rp. 11.000 & 1.100 gram & 1.104 gram & 4 gram \\
\hline 12 & Rp. 12.000 & 1.200 gram & 1.207 gram & 7 gram \\
\hline 13 & Rp. 13.000 & 1.300 gram & 1.308 gram & 8 gram \\
\hline 14 & Rp. 14.000 & 1.400 gram & 1.408 gram & 8 gram \\
\hline 15 & Rp. 15.000 & 1.500 gram & 1.502 gram & 2 gram \\
\hline 16 & Rp. 16.000 & 1.600 gram & 1.606 gram & 6 gram \\
\hline 17 & Rp. 17.000 & 1.700 gram & 1.705 gram & 5 gram \\
\hline 18 & Rp. 18.000 & 1.800 gram & 1.810 gram & 10 gram \\
\hline 19 & Rp. 19.000 & 1.900 gram & 1.909 gram & 9 gram \\
\hline 20 & Rp. 20.000 & 2.000 gram & 2.003 gram & 3 gram \\
\hline 21 & Rp. 21.000 & 2.100 gram & 2.102 gram & 1 gram \\
\hline 22 & Rp. 22.000 & 2.200 gram & 2.202 gram & 2 gram \\
\hline 23 & Rp. 23.000 & 2.300 gram & 2.302 gram & 2 gram \\
\hline
\end{tabular}

\begin{tabular}{|c|c|c|c|c|}
\hline 24 & Rp. 24.000 & 2.400 gram & 2.410 gram & 10 gram \\
\hline 25 & Rp. 25.000 & 2.500 gram & 2.510 gram & 10 gram \\
\hline 26 & 100 gram & 100 gram & 113 gram & 16 gram \\
\hline 27 & 200 gram & 200 gram & 210 gram & 17 gram \\
\hline 28 & 300 gram & 300 gram & 308 gram & 16 gram \\
\hline 29 & 400 gram & 400 gram & 409 gram & 9 gram \\
\hline 30 & 500 gram & 500 gram & 507 gram & 7 gram \\
\hline 31 & 600 gram & 600 gram & 607 gram & 7 gram \\
\hline 32 & 700 gram & 700 gram & 704 gram & 4 gram \\
\hline 33 & 800 gram & 800 gram & 807 gram & 7 gram \\
\hline 34 & 900 gram & 900 gram & 905 gram & 5 gram \\
\hline 35 & 1.000 gram & 1.000 gram & 1.003 gram & 3 gram \\
\hline 36 & 1.100 gram & 1.100 gram & 1.104 gram & 4 gram \\
\hline 37 & 1.200 gram & 1.200 gram & 1.207 gram & 7 gram \\
\hline 38 & 1.300 gram & 1.300 gram & 1.308 gram & 8 gram \\
\hline 39 & 1.400 gram & 1.400 gram & 1.408 gram & 8 gram \\
\hline 40 & 1.500 gram & 1.500 gram & 1.502 gram & 2 gram \\
\hline 41 & 1.600 gram & 1.600 gram & 1.606 gram & 6 gram \\
\hline 42 & 1.700 gram & 1.700 gram & 1.705 gram & 5 gram \\
\hline 43 & 1.800 gram & 1.800 gram & 1.810 gram & 10 gram \\
\hline 44 & 1.900 gram & 1.900 gram & 1.909 gram & 9 gram \\
\hline 45 & 2.000 gram & 2.000 gram & 2.003 gram & 3 gram \\
\hline 46 & 2.100 gram & 2.100 gram & 2.102 gram & 2 gram \\
\hline 47 & 2.200 gram & 2.200 gram & 2.202 gram & 2 gram \\
\hline 48 & 2.300 gram & 2.300 gram & 2.303 gram & 3 gram \\
\hline 49 & 2.400 gram & 2.400 gram & 2.410 gram & 10 gram \\
\hline 50 & 2.500 gram & 2.500 gram & 2.509 gram & 9 gram \\
\hline & & & & \\
\hline
\end{tabular}

\section{Beras B (harga Rp 9.000/kg)}

\begin{tabular}{|c|c|c|c|c|}
\hline \multirow[b]{2}{*}{ No } & \multirow[b]{2}{*}{ Pembelian } & \multicolumn{2}{|c|}{ Hasil } & \multirow[b]{2}{*}{ Sesilih } \\
\hline & & $\begin{array}{c}\text { Timbangan } \\
\text { Alat }\end{array}$ & $\begin{array}{c}\text { Timbangan } \\
\text { Digital }\end{array}$ & \\
\hline 1 & Rp. 1.000 & 111 gram & 129 gram & 18 gram \\
\hline 2 & Rp. 2.000 & 222 gram & 238 gram & 16 gram \\
\hline 3 & Rp. 3.000 & 333 gram & 347 gram & 16 gram \\
\hline 4 & Rp. 4.000 & 444 gram & 454 gram & 10 gram \\
\hline 5 & Rp. 5.000 & 556 gram & 565 gram & 9 gram \\
\hline 6 & Rp. 6.000 & 667 gram & 675 gram & 8 gram \\
\hline 7 & Rp. 7.000 & 778 gram & 786 gram & 8 gram \\
\hline 8 & Rp. 8.000 & 889 gram & 896 gram & 7 gram \\
\hline 9 & Rp. 9.000 & 1.000 gram & 1.009 gram & 9 gram \\
\hline 10 & Rp. 10.000 & 1.111 gram & 1.117 gram & 6 gram \\
\hline 11 & Rp. 11.000 & 1.222 gram & 1.224 gram & 2 gram \\
\hline 12 & Rp. 12.000 & 1.333 gram & 1.336 gram & 3 gram \\
\hline 13 & Rp. 13.000 & 1.444 gram & 1.446 gram & 2 gram \\
\hline 14 & Rp. 14.000 & 1.556 gram & 1557 gram & 1 gram \\
\hline 15 & Rp. 15.000 & $1.667 \mathrm{gram}$ & 1.700 gram & 3 gram \\
\hline 16 & Rp. 16.000 & 1.778 gram & 1.788 gram & 10 gram \\
\hline 17 & Rp. 17.000 & 1.889 gram & $1.895 \mathrm{gram}$ & 6 gram \\
\hline 18 & Rp. 18.000 & 2.000 gram & 2.006 gram & 6 gram \\
\hline 19 & Rp. 19.000 & 2.111 gram & 2.116 gram & 5 gram \\
\hline 20 & Rp. 20.000 & $2.222 \mathrm{gram}$ & 2.236 gram & 13 gram \\
\hline 21 & Rp. 21.000 & 2.333 gram & 2.346 gram & 13 gram \\
\hline 22 & Rp. 22.000 & 2.444 gram & 2.454 gram & 10 gram \\
\hline 23 & Rp. 23.000 & 2.556 gram & 2.567 gram & 11 gram \\
\hline 24 & Rp. 24.000 & 2.667 gram & 2.678 gram & 11 gram \\
\hline 25 & Rp. 25.000 & 2.778 gram & 2.790 gram & 12 gram \\
\hline 26 & 100 gram & 100 gram & 118 gram & 17 gram \\
\hline 27 & 200 gram & 200 gram & 216 gram & 16 gram \\
\hline 28 & 300 gram & 300 gram & 312 gram & 16 gram \\
\hline 29 & 400 gram & 400 gram & 410 gram & 10 gram \\
\hline 30 & 500 gram & 500 gram & 513 gram & 16 gram \\
\hline 31 & 600 gram & 600 gram & 609 gram & 9 gram \\
\hline 32 & 700 gram & 700 gram & 708 gram & 8 gram \\
\hline 33 & 800 gram & 800 gram & 809 gram & 9 gram \\
\hline
\end{tabular}




\begin{tabular}{|c|c|c|c|c|}
\hline 34 & 900 gram & 900 gram & 910 gram & 10 gram \\
\hline 35 & 1.000 gram & 1.000 gram & 1.009 gram & 9 gram \\
\hline 36 & 1.100 gram & 1.100 gram & 1.108 gram & 8 gram \\
\hline 37 & 1.200 gram & 1.200 gram & 1.207 gram & 7 gram \\
\hline 38 & 1.300 gram & 1.300 gram & 1.304 gram & 4 gram \\
\hline 39 & 1.400 gram & 1.400 gram & 1.405 gram & 5 gram \\
\hline 40 & 1.500 gram & 1.500 gram & 1.507 gram & 7 gram \\
\hline 41 & 1.600 gram & 1.600 gram & 1.603 gram & 3 gram \\
\hline 42 & 1.700 gram & 1.700 gram & 1.705 gram & 5 gram \\
\hline 43 & 1.800 gram & 1.800 gram & 1.810 gram & 10 gram \\
\hline 44 & 1.900 gram & 1.900 gram & 1.894 gram & 6 gram \\
\hline 45 & 2.000 gram & 2.000 gram & 1.995 gram & 5 gram \\
\hline 46 & 2.100 gram & 2.100 gram & 2.112 gram & 12 gram \\
\hline 47 & 2.200 gram & 2.200 gram & 2.211 gram & 11 gram \\
\hline 48 & 2.300 gram & 2.300 gram & 2.290 gram & 10 gram \\
\hline 49 & 2.400 gram & 2.400 gram & 2.416 gram & 16 gram \\
\hline 50 & 2.500 gram & 2.500 gram & 2.515 gram & 15 gram \\
\hline
\end{tabular}

\section{Beras C (harga Rp 8.000/kg)}

\begin{tabular}{|c|c|c|c|c|}
\hline \multirow[b]{2}{*}{ No } & \multirow[b]{2}{*}{ Pembelian } & \multicolumn{2}{|c|}{ Hasil } & \multirow[b]{2}{*}{ Sesilih } \\
\hline & & $\begin{array}{c}\text { Timbangan } \\
\text { Alat }\end{array}$ & $\begin{array}{c}\text { Timbangan } \\
\text { Digital }\end{array}$ & \\
\hline 1 & Rp. 1.000 & 125 gram & 138 gram & 16 gram \\
\hline 2 & Rp. 2.000 & 250 gram & 255 gram & 17 gram \\
\hline 3 & Rp. 3.000 & 375 gram & 386 gram & 16 gram \\
\hline 4 & Rp. 4.000 & 500 gram & 515 gram & 14 gram \\
\hline 5 & Rp. 5.000 & 625 gram & 639 gram & 16 gram \\
\hline 6 & Rp. 6.000 & 750 gram & 761 gram & 11 gram \\
\hline 7 & Rp. 7.000 & 875 gram & 885 gram & 10 gram \\
\hline 8 & Rp. 8.000 & 1.000 gram & 1.015 gram & 14 gram \\
\hline 9 & Rp. 9.000 & 1.125 gram & 1.136 gram & 11 gram \\
\hline 10 & Rp. 10.000 & 1.250 gram & 1.262 gram & 12 gram \\
\hline 11 & Rp. 11.000 & 1.375 gram & 1.388 gram & 13 gram \\
\hline 12 & Rp. 12.000 & 1.500 gram & 1.515 gram & 15 gram \\
\hline 13 & Rp. 13.000 & 1.625 gram & 1.640 gram & 15 gram \\
\hline 14 & Rp. 14.000 & 1.750 gram & 1.764 gram & 14 gram \\
\hline 15 & Rp. 15.000 & 1.875 gram & 1.889 gram & 14 gram \\
\hline 16 & Rp. 16.000 & 2.000 gram & 2.009 gram & 9 gram \\
\hline 17 & Rp. 17.000 & 2.125 gram & 2.127 gram & 2 gram \\
\hline 18 & Rp. 18.000 & 2.250 gram & 2.252 gram & 2 gram \\
\hline 19 & Rp. 19.000 & 2.375 gram & 2.376 gram & 1 gram \\
\hline 20 & Rp. 20.000 & 2.500 gram & 2.501 gram & 1 gram \\
\hline 21 & Rp. 21.000 & 2.625 gram & 2.627 gram & 2 gram \\
\hline 22 & Rp. 22.000 & 2.750 gram & 2.751 gram & 1 gram \\
\hline 23 & Rp. 23.000 & 2.875 gram & 2.880 gram & 5 gram \\
\hline 24 & Rp. 24.000 & 3.000 gram & 3.002 gram & 2 gram \\
\hline 25 & Rp. 25.000 & 3.125 gram & 3.129 gram & 4 gram \\
\hline 26 & 100 gram & 100 gram & 117 gram & 17 gram \\
\hline 27 & 200 gram & 200 gram & 215 gram & 16 gram \\
\hline 28 & 300 gram & 300 gram & 314 gram & 16 gram \\
\hline 29 & 400 gram & 400 gram & 410 gram & 10 gram \\
\hline 30 & 500 gram & 500 gram & 511 gram & 11 gram \\
\hline 31 & 600 gram & 600 gram & 612 gram & 12 gram \\
\hline 32 & 700 gram & 700 gram & 713 gram & 13 gram \\
\hline 33 & 800 gram & 800 gram & 812 gram & 12 gram \\
\hline 34 & 900 gram & 900 gram & 912 gram & 12 gram \\
\hline 35 & 1.000 gram & 1.000 gram & 1.011 gram & 11 gram \\
\hline 36 & 1.100 gram & 1.100 gram & 1.112 gram & 12 gram \\
\hline 37 & 1.200 gram & 1.200 gram & 1.213 gram & 13 gram \\
\hline 38 & 1.300 gram & 1.300 gram & 1.315 gram & 15 gram \\
\hline 39 & 1.400 gram & 1.400 gram & 1.414 gram & 14 gram \\
\hline 40 & 1.500 gram & 1.500 gram & 1.515 gram & 15 gram \\
\hline 41 & 1.600 gram & 1.600 gram & 1.612 gram & 12 gram \\
\hline 42 & 1.700 gram & 1.700 gram & 1712 gram & 12 gram \\
\hline 43 & 1.800 gram & 1.800 gram & 1.811 gram & 11 gram \\
\hline
\end{tabular}

\begin{tabular}{|l|l|l|l|l|}
\hline 44 & 1.900 gram & 1.900 gram & 1.912 gram & 12 gram \\
\hline 45 & 2.000 gram & 2.000 gram & 2.006 gram & 6 gram \\
\hline 46 & 2.100 gram & 2.100 gram & 2.107 gram & 7 gram \\
\hline 47 & 2.200 gram & 2.200 gram & 2.208 gram & 8 gram \\
\hline 48 & 2.300 gram & 2.300 gram & 2.305 gram & 5 gram \\
\hline 49 & 2.400 gram & 2.400 gram & 2.404 gram & 4 gram \\
\hline 50 & 2.500 gram & 2.500 gram & 2.504 gram & 4 gram \\
\hline
\end{tabular}

Dari tabel diatas menunjukkan bahwa sensor loadcell berjalan dengan stabil. Terbukti dengan selisih timbangan yang tidak berubah secara signifikan dengan selisih paling kecil sebesar 1 gram dan selisih paling besar sebesar 15 gram, meskipun input nilai berbeda-beda.

Untuk menentukan jumlah berapa gram yang diperoleh menggunakan rumus sistem linier dua variabel nanti diimplementasikan pada program :

Hasil penelitian dibahas dan dibandingkan dengan hasil penelitian dari artikel yang diacu, jika mungkin.

Untuk menentukan jumlah berapa gram yang diperoleh menggunakan rumus sistem linier dua variabel nanti diimplementasikan pada program :

$$
\mathrm{ax}-\mathrm{by}=0
$$

Dimana : $\mathrm{x}=$ harga beras

$$
\begin{aligned}
& y=\text { berat beras } \\
& a=\text { input berat } \\
& b=\text { input harga }
\end{aligned}
$$

Misal kita ingin membeli beras $\mathrm{C}$ dengan harga 1000 gram adalah 8.000 rupiah. Jika ingin membeli 5.000 rupiah saja maka beras yang kita dapat adalah ...

Diketahui : $\mathrm{a}=$ ? gram

$$
\begin{aligned}
& \mathrm{b}=5.000 \text { rupiah } \\
& \mathrm{x}=8.000 \text { rupiah } \\
& \mathrm{y}=1.000 \text { gram }
\end{aligned}
$$

Maka :

$$
\begin{array}{ll}
\mathrm{a}(8.000)-5.000(1.000) & =0 \\
8.000 \mathrm{a}-5.000 .000 & =0 \\
8.000 \mathrm{a} & =5.000 .000 \\
\mathrm{a} & =5.000 .000 / 8.000 \\
\mathrm{a} & =625 \text { gram }
\end{array}
$$

Jadi berat beras yang diperoleh adalah sebesar $\mathbf{6 2 5}$ gram.

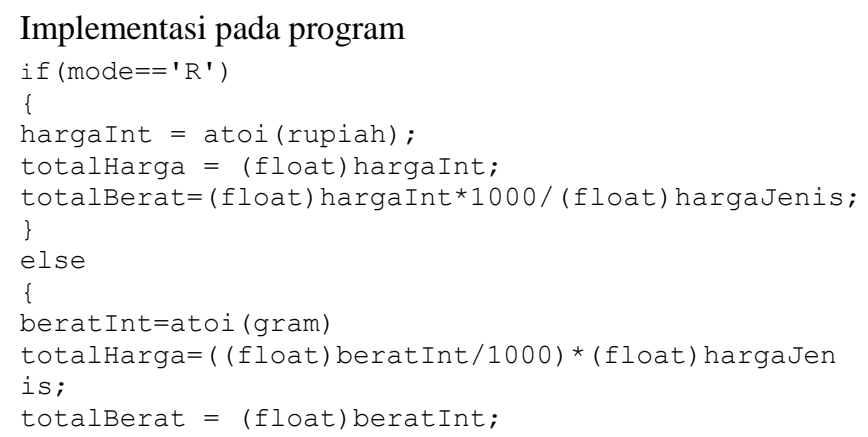




\section{E. Analisa}

Pengujian hardware dan software secara keseluruhan dilakukan dengan cara melakukan pembelian sebanyak 150 kali Masing-masih 50 kali pada setiap jenis beras. Pada pengujian beras A dilakukan percobaan dengan menggunakan jenis pembelian rupiah dimulai dari 1.000 rupiah sampai 25.000 rupiah dan jenis pembelian menggunakan input gram dimulai dari pembelian 100 gram sampai 2.500 gram. Hasil dari percobaan beras A didapat grafik sebagai berikut

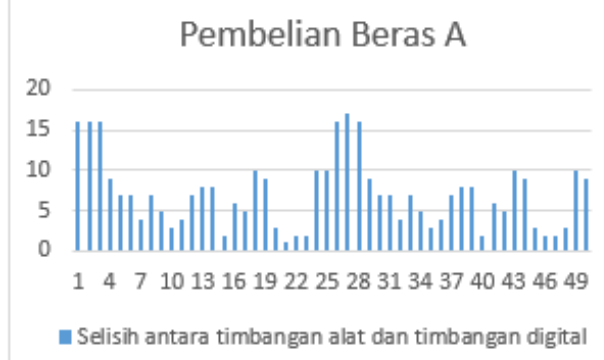

Dari grafik di sumbu X menunjukkan jumlah percobaan 1 sampai 50 sedangkan sumbu $\mathrm{Y}$ menunjukkan jumlah selisih timbangan alat dengan timbangan digital. Hasil dari 50 kali percobaan pembelian beras A yaitu sebanyak 6 percobaan memiliki selisih timbang lebih dari 15 gram, 44 kurang dari 15 gram.

Presentasi Keberhasilan $=\frac{\text { Jumlah keberhasilan }}{\text { Jumlah percobaan }} \times 100 \%$ Presentasi Keberhasilan $=\frac{44}{50} \times 100 \%=88 \%$

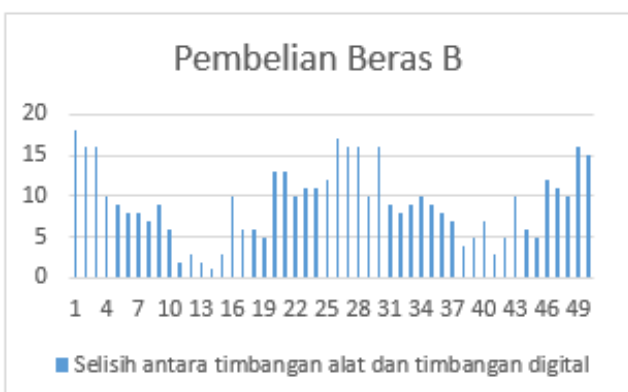

Hasil dari grafik di atas dari 50 kali percobaan pembelian beras B yaitu sebanyak 8 percobaan memiliki selisih timbang lebih dari 15 gram, 42 kurang dari 15 gram.

Presentasi Keberhasilan $=\frac{42}{50} \times 100 \%=84 \%$

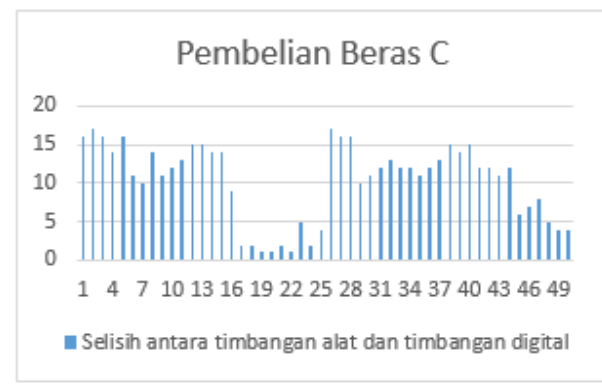

Hasil dari grafik di atas dari 50 kali percobaan pembelian beras $\mathrm{C}$ yaitu sebanyak 7 percobaan memiliki selisih timbang lebih dari 15 gram, 43 kurang dari 15 gram.

$$
\text { Presentasi Keberhasilan }=\frac{43}{50} \times 100 \%=86 \%
$$

Secara keseluruhan percobaan yang telah dilakukan dapat disimpulkan bahwa rancang bangun mesin penjual beras ini memiliki selisih 0-15 gram. Kesalahan/error ini sudah termasuk bagus untuk alat ini. Proses pengisian beras dari awal servo buka sampai set point membutuhkan waktu kurang lebih 30 detik / 1.000 gram

\section{KESIMPULAN}

Kesimpulan yang diperoleh dari percobaan alat :

1.Dari percobaan pembelian mesin penjual beras pada beras A didapatkan hasil presentase keberhasilan sebesar $88 \%$, beras B sebesar $84 \%$, beras C sebesar $86 \%$.

2.Timbangan pada alat memiliki selisih 1-15 gram dibandingkan dengan timbangan digital.

Adapun saran untuk penelitian selanjutnya :

1.Pada penelitian selanjutnya sebaikknya menggunakan sensor yang lebih presisi agar pembacaan lebih akurat.

2.Memperbaiki desain penjual beras.

\section{REFERENSI}

[1] Ulum Miftachul, I. Achmad Fiqhi dan A. Hirvy Nurul "Alat Pemantau Kondisi infus dengan Internet of Things (IOT) berbasis Atmega16" Jurnal TRIAC, Vol. 5 No. 1, 2018

[2] Wahyu Setyo Pambudi dan Imam Suhendra, "Aplikasi Load Cell Untuk Otomasi Pada Depot Air Minum Isi ulang”, vol. 1, no. 1, pp. 12-19, 2015

[3] Rahmat dan Wiyono, "Pengendali Motor Servo Posisi dengan Kendali PID Berbasis Mikrokontroler Atmega Pengendali Motor Servo Posisi dengan Kendall Pid," no. March, pp. 15-29, 2018.

[4] P. M. N. Manege, E. K. Allo, and J. T. Elektro-ft, "Rancang Bangun Timbangan Digital Dengan Kapasitas 20Kg Berbasis Microcontroller Atmega8535," J. Tek. Elektro dan Komput., vol. 6, no. 1, pp. 57-62, 2017, doi: 10.35793/jtek.6.1.2017.16123.

[5] Mirfan, "Mesin penyaji beras secara digital," J. Ilm. Ilk., vol. 8, no. Agustus, pp. 126-131, 2016

[6] G. Fajar and Wildian, "Rancang Bangun Prototipe Spbu-Mini Berbasis Mikrokontroler Atmega8535 Dengan Keluaran Berdasarkan Nilai Masukan Dalam Rupiah” J. Fis. Unand, vol. 4, no. 1, pp. 4350, 2015.

[7] N. A. Latha and B. R. Murthy, "Arduino based Weighting Scale using Load Cell,” vol. 3, no. 6, pp. 704-707, 2017.

[8] R. Aravind, A. E. Kumar, K. Harisudhan R, G. Karan, Raj, and G. Udhayakumar, "Load Cell based Fuel Level Measurement using Arduino Uno Microcontroller," Int. J. Adv. Res. Dev., vol. 3, pp. 159-164, 2018.

[9] Nurlette Dirman, W Toni Kusuma "Perancangan Alat Pengukur Tinggi Dan Berat Badan Ideal Berbasis Arduino", Jurnal Sigma Teknika, Vol. 1, No. 2 : 172-184, 2018

[10] Hidayat, M Ridlo Ferari, "Rancang Bangun Perangkat Elektronik penampil Teks Dalam Kode Braille Berbasis Mikrokontroler” Jurnal Teknik Komputer Unikom, Vol. 3, No. 1, 2015 